\title{
The Indonesian Islamic banking: interrelation between intellectual capital performance, intellectual capital disclosure, and financial performance
}

\author{
Ihyaul Uluma ${ }^{1}$, Oky Bon Amarullah ${ }^{2}$, Eny Suprapti ${ }^{3}$ \\ \{Ihyaul@umm.ac.id,okybon@gmail.com,e.suprapti@yahoo.com \} \\ Accounting Department University of Muhammadiyah Malang, Indonesia
}

\begin{abstract}
The purpose of this study is to post a view point on intellectual capital performance and intellectual capital disclosure based on Indonesian Islamic banking. This paper add financial performance (measured with profitability ratio) as a mediator on the relationship between intellectual capital performance and intellectual capital disclosure. A four way numerical coding system was used to conduct content analysis. Sample was drawn from Indonesian Islamic banking for five years observation, 2011-2015. The results from WarpPLS 3.0 showed that intellectual capital performance (measured with modified value added intellectual coefficient/MVAIC) has a significant effect to the level of intellectual capital disclosure. Contrasting with our hypothesis, financial performance of Indonesian Islamic banking did not mediate the relationship between intellectual capital performance and intellectual capital disclosure.
\end{abstract}

Keywords: financial performance, intellectual capital disclosure, intellectual capital performance

\section{Introduction}

The business world is growing to change the mindset of businesses that the ability to compete not only in the ownership of tangible assets, but rather on innovation, information systems, organizational management and organizational resources. The success of the agent (manager of capital) runs a business from the owners of capital (principle), this can be seen from the increase in the market value of the company they manage. The difference between the market value and the book value of the company as the Intellectual Capital (IC) value.

In Indonesia, Intellectual Capital has been recognized and addressed in the Statement of Financial Accounting Standard (IAS) 19 (revised 2010) on intangible assets. In those standards, the IC is not discussed widely, but the IC component (goodwill) has been discussed about their accounting treatment. This standard also does not address all components of the IC, and the goodwill generated should be from votes of external parties (appraiser). In this regard, IAS 22 (revised 2010) about a business combination, stating that the goodwill arising from the acquisition will no longer be amortized but must be subjected to an impairment test each year by means of the test described in IAS 48 (Revised 2009) on impairment of assets.

Today, studies that examine the direct relationship between intellectual capital performances (ICP) with the disclosure of intellectual capital (ICD) are still rare. Uses 30 public companies in the UK are included in the FTSE 100 group to analyze the practice of IC disclosure in its annual report and its relation to the performance of IC (ICP) and the results of intellectual 
capital performance negatively affect the intensity of the intellectual capital disclosures [1]. Williams argued that the company reduces intellectual capital disclosures when ICP reaches a threshold, because fear of missing their competitive advantage [2]-[4].

Still lack of studies that examine the relationship between ICP and ICD give space to do further study. This study examined the direct effect of ICP (measured with Modified value added intellectual coefficient/MVAIC) to the level of ICD and its indirect effect through profitability as mediator variable. Public companies in Islamic banking sector was used as sample groups.

\section{Literature Review}

The study of 30 public companies in the UK are included in the FTSE 100 group to analyze the practice of IC disclosure in its annual report and its relation to the performance of IC (ICP) [1]. The results showed that the ICP is negatively related to the practice of IC disclosure in the annual report of the company.

The relationship between intellectual capital performance and the disclosure practices of public companies included in the 50 Biggest Market Capitalization of public model (VAICTM) [5]. The results showed that ICP is negatively related to ICD. The relationship between Intellectual Capital (ICP) and the financial performance of companies manufacturing [6]. In this case, ICP is measured by using (VAIC TM) and financial performance by using (ROA, ROE, and EPS). The results of this study are ICP affecting the financial performance (ROA, ROE, and EPS).

The relationship between the performance of intellectual capital as measured by the CEE (Capital Employed Efficiency), HCE (Human Capital Efficiency), SCE (Structural Capital Efficiency) and the disclosure of intellectual capital (ICD) by placing financial performance (profitability) as mediator variable, while sample used in this study were banking companies listed on the Stock Exchange [7]. The result shows that the CEE, HCE and SCE have no direct effect for the ICD, the indirect effect of the CEE for ICD is greater if through ROA, and ROA affect the ICD. The relationship between intellectual capital performance (ICP) and extensive disclosure (ICD) on the performance and value of the company at 87 pharmaceutical companies, telecommunications, and banking which are listed on the Indonesian Stock Exchange (BEI) [8]. The method used is multiple linear regression and the results showed that the ICP and ICD significantly has positive effect on corporate performance (ROA). ICP and ICD also have a positive effect on firm value (Tobin's q), but not significantly.

Voluntary disclosure on intellectual capital allows investors and other stakeholders to be better assessing the ability of the company in the future, conducting a proper assessment of the company, and reducing their risk perception [1]. Companies disclose Intellectual Capital in their financial statements in order to meet the information needs of investors, as well as increasing the value of the company [9]. Positive signals from the organization is expected to get a positive response from the market, it can provide a competitive advantage for the company and can be an attraction for investors.

Empirical studies that examine the direct relationship (direct model) between ICP with ICD is still rare. Most of the published research puts more characteristics of the company as a factor antecedent of ICD [10]. Uses 30 public companies in the UK are included in the FTSE 100 group to analyze the practice of IC disclosure in its annual report and relation to the performance of IC (ICP) [1]. The results showed that the ICP is negatively related to the practice of IC disclosure in the annual report of the company, the same results were also found [5]. Both of 
these results were later confirmed by [11] which puts ICD as mediator between ICP with a market capitalization (MCAP) and using a sample of public companies banking sector in Indonesia.

All three results of these studies contradict the theory of RBT and Signaling Theory. According to signaling theory, companies that have good performance of IC tend to disclose more information about its IC (e.g., through annual reports and voluntary disclosure). While in the perspective of RBT, IC is a resource that can help companies to achieve competitive advantage, and thus should have a high ICP as a very good signal for the company. Thus, the first hypothesis in this study is:

\section{H1: Intellectual capital performance (ICP) has Positive Effect on Intellectual Capital Disclosure (ICD)}

The direct effect of ICP on ICD has been proved empirically by some researchers, such as: $[1],[5],[10]$ and the result was negative. However, a different result is likely to occur indirectly, through ROA.

Based on the stakeholder theory, "Stakeholders have the authority to influence the management in the process of exploiting all potential of the organization." In this context the management is required to be able retaining and utilizing the important strategic assets (tangible and intangible assets) in the company.

Based on theory RBT, when management is able to manage, control, and utilize resources (both tangible and intangible), then the company's competitive advantage will be achieved. A strong competitive advantage will make the company as the market leader, it is certainly going to affect very well against the company, of course the resulted products will be received very well by the community. When the product is received by the public and then more and more consumers will inevitably increase the company's revenue. The impact will be evident in improved financial performance of the company. Based on these conditions, the company (manager) will attempt to show the signal in the form of positive information (improved financial performance as a result of the management of tangible and intangible assets or can be intellectual capital) to potential investors through voluntary disclosures in annual financial statements. Thus, the second hypothesis in this study is:

\section{H2: Financial performance (ROA) Mediates the Relationships between Intellectual Capital Performance (MVAIC) with Intellectual Capital Disclosure (ICD)}

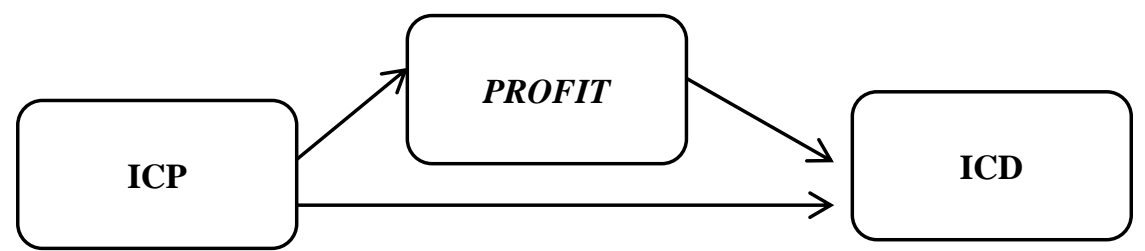

Fig 1. Empirical Model 


\section{Methodology}

This research is associative by taking the object Islamic Bank, consisting of Islamic Public Banks (IPB) and Sharia Enterprises Unit (SEU). The sampling technique used was purposive sampling with criteria: 1) Company is registered in Bank Indonesia for the period 2011-2015, 2) Presenting financial statements and annual financial statements in period 2011-2015 consecutively, and inaccessible, 3 ) the Company did not experience a loss during the period 2011-2015. Data obtained directly from the official website of each bank were investigated in the period 2011-2015 with the technical documentation.

The independent variables in this study are the intellectual capital performance. Measurement of intellectual capital performance is using MVAIC. Stages of MVAIC calculation is as follows: Stage I: Calculating a Value Added (VA)

$$
\mathrm{VA} \quad=\mathrm{OP}+\mathrm{EC}+\mathrm{D}+\mathrm{A}
$$

Stage II: Calculating the efficiency of the IC (ICE)

$$
\mathrm{ICE}=\mathrm{HCE}+\mathrm{SCE}+\mathrm{RCE}
$$

$\mathrm{HCE}=\mathrm{VA} / \mathrm{HC}$

$\mathrm{SCE} \quad=\mathrm{SC} / \mathrm{VA}$

$\mathrm{RCE}=\mathrm{RC} / \mathrm{VA}$

Stage III : Calculating the efficiency of capital employed (CCE)

$\mathrm{CEE} \quad=\mathrm{VA} / \mathrm{CE}$

Stage IV ; Resulting MVAIC

$\mathrm{MVAIC}=\mathrm{ICE}+\mathrm{CEE}$

MVAIC $=(\mathrm{HCE}+\mathrm{SCE}+\mathrm{RCE})+\mathrm{CEE}$

The dependent variable in this study is the disclosure of intellectual capital that is obtained by referring to the framework of the 36 items or can be referred to the ICD-In (Intellectual Capital Disclosure Indonesia) [10]. The identification process is done in 4 ways ICD system a numeric code (a four-way numerical coding system) developed by Guthrie, Petty, Ferrier, and Wells (1999). This method not only identifies IC broad disclosure of aspects of quantity, but also quality of its disclosure [12].

ICD was calculated by comparing the total components of the ICD-In revealed and compared with the overall total of components (36 Items) ICD = Total disclosed $/$ total items ICD-In. Mediator variable in this research is financial performance. Measurement of financial performance uses ROA. ROA reflects the business benefits and efficiency in the utilization of total assets (Brigham \& Houston, 2011). ROA = net income / total assets.

Data analysis technique is done by: (1) Content analysis and (2) WarpPLS 3.0. PLS is a method of settling the structural equation modelling (SEM), which in this case (according to research purposes), gives an idea of testing illustration or indirect influence corresponding to this research is more precise than the other SEM techniques. Selection of PLS method is also based on the consideration that in this study there are three latent variables are formed with formative indicators, and not reflexive. The formative model assumes that the indicators affect the construct, where the causality direction of indicators to construct [13].

Because the testing of each variable using a sample of more than one year, then to test the independent variable (ICD) will be given control to every year by providing dummy score, which is a value of 1 for the analysis of data to the year under study and the value 0 for data other than the year studied. It aims to control the influence of variables ICP-ICD in order to obtain maximum results in this study later. 
Researchers using four-away numerical coding system to identify the extent and Intellectual Capital disclosures in the annual report of the company [14]. Intellectual Capital disclosure in the annual report is weighted according to the projections. Numeric codes used are:

0 : item is not disclosed in the annual report.

$1:$ item is disclosed in narrative form.

$2:$ item is disclosed in numerical form.

$3:$ item is disclosed in monetary value.

In addition to seeing the value of r-square, the pls model also evaluated with viewing full co-linearity VIP and q-square predictive relevance to every latent variables used in this study. Full co-linearity VIP is full of co-linearity test results which include vertical multi colinearity, lateral and common method bias, while the q-square predictive relevance is used to measure how fit the observed values generated by the model and parameter estimation. Full colinearity vif value should be below 3.3 [15] for each latent variable that no matter vertical multi co-linearity, lateral and common method bias. Q-square predictive value relevance over 0 indicates that the model has predictive relevance value, while the value of the q-square predictive relevance of less than 0 indicates that the model lacks predictive relevance [13].

The last stage is hypothesis-testing procedure of financial performance as a mediator variable for relationship between icp and icd using the regression phase [16]:

Step 1: estimating the direct effect of icp toward icd.

Step 2: estimating the indirect effect simultaneously with sem pls triangle model which icpicd, icp-profitability, and profitability-icd.

\section{Empirical results and discussion}

\subsection{Content analysis}

Identification results of content analysis are presented in Figure 2, a content analysis is done by identifying the components of icd-in disclosed in the annual financial statements of islamic banks and sharia business unit with the observation period from 2011 to 2015, then each disclosures were scored using four-away numerical coding system.

Based on the results of content analysis as presented in Figure 2 shows the overall ic information disclosed in narrative form dominating type of disclosure, which is in the range of $48.96 \%$ to $54.71 \%$. This figure is above the percentage should be, that is $36.11 \%$, while the ic information disclosed in numerical form in the range of $12: 06 \%$ to $14.93 \%$ of which should reach $50 \%$, while the ic information is presented in the form of the currency were far enough away from the supposed (13.89\%), i.e. Between $3.60 \%$ to $6: 25 \%$ [12].

Percentage of intellectual capital items which were not disclosed (score $=0$ ) is clearly seen in figure 2 has decreased constantly from year to year, which amounted to $35.38 \%$ in 2011 to $24.65 \%$ by 2015 . This condition shows that awareness of the importance of disclosure of intellectual capital in both the islamic banks, and sharia business unit are already becoming visible. This means that the manager believes that more information is disclosed regarding intellectual capital (icd) will be have a more positive influence on the company or in other words, will benefit the company. 


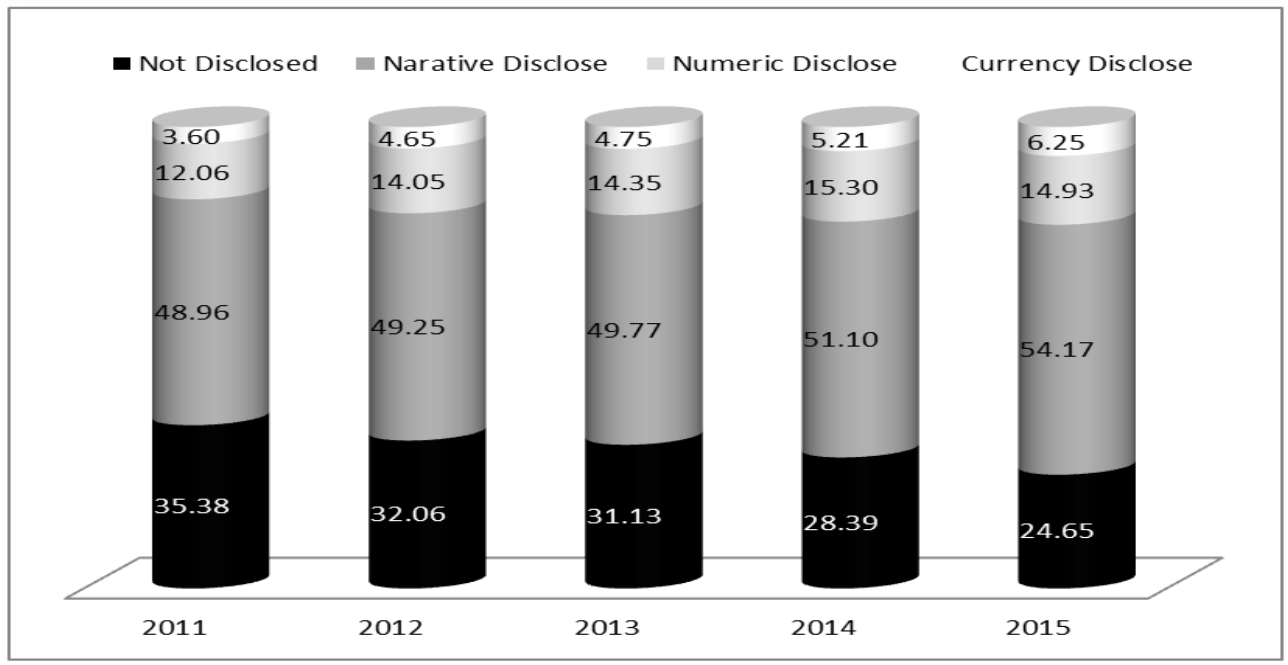

Fig 2. Content analysis results

\subsection{Testing hypothesis with warppls}

In testing the hypothesis with warppls there are two steps that should be first, which assesses and evaluates the models and outer inner models or so-called structural models. After these two conditions are met, then the hypothesis testing can be done, and the steps taken in this study can be seen as follows:

a. Assessing the outer model or measurement models

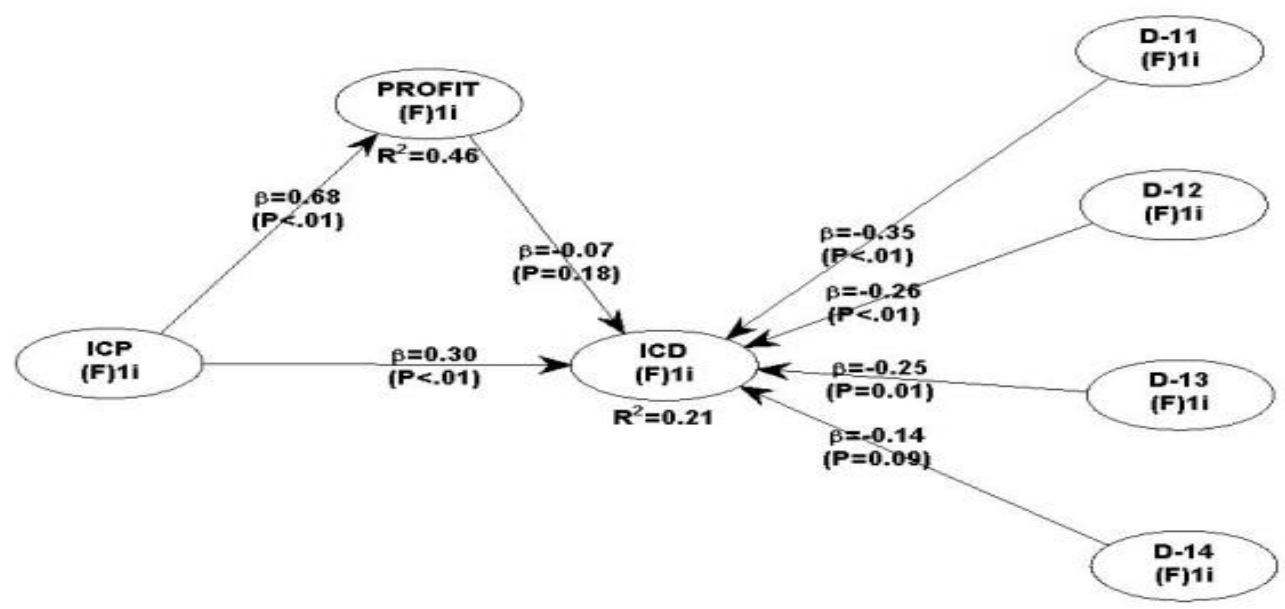

Fig 2. Output WarpPLS 3.0- full model

The test result with warppls 3.0 is presented in figure 3 , table 1 . Based on the output 'model fit indices and $p$ value' in the table it is known that the value of apc $=0.293, p<0.001$, ars $=0.333$, 
$\mathrm{p}=<0.001$ and avif $=1.457$, good if $<3.3$. Warppls provision states that the $\mathrm{p}$ value for the apc and ars should be less than 0.05 (significant). In addition, avif as an indicator of multi colinearity must be smaller than 3.3. Referring to these provisions, it can be concluded that this research model is fit. So that the testing process by warppls can be continued by testing inner models, because the criteria the model fit in the assessment of model outer has been fulfilled and no problems do not fit from the model of the three formative latent variables.

Figure 2 and Table 1 show the path coefficients and $\mathrm{P}$ value of any direct relation (direct effect) in our model, as well as any control year for the independent variables (ICD). Path of ICP-ICD shows 0.303 coefficient was significant at $\mathrm{P}<0.001(* * *)$, path of ICP-PROFIT coefficient value of 0.676 indicates significant at $\mathrm{P}<0.01(* * *)$, while path of PROFIT-ICD shows the value of the coefficient -0.072 and not significant. Controls of year for each year of the independent variables, namely: D11-ICD -0.346 is significant at $<0.001(* * *)$, D12-ICD 0.264 to be significant at $\mathrm{p}=0.005(* * *), \mathrm{D} 13-\mathrm{ICD}-0.250$ to be significant at $\mathrm{p}=0.12(* * *), \mathrm{D} 14$ ICD -0.138 to be significant at $\mathrm{p}=0.088(* *)$.

Table 1. Model fit indices, Path coefficients and $\mathrm{P}$ value

\begin{tabular}{lll}
\hline Model fit indices and P values & APC $=0.293, \mathrm{P}<0.001$ \\
& $\mathrm{ARS}=0.333, \mathrm{P}<0.001$ & \\
& $\mathrm{AVIF}=1.457$, Good if $<5$ & \\
Patch coefficients and P Values & ICP-ICD & $0.303, \mathrm{P}<0.001$ \\
& ICP-ROA & $0.676, \mathrm{P}<0.001$ \\
& ROA-ICD & $-0.072, \mathrm{P}=0.179$ \\
& D11-ICD & $-0.346, \mathrm{P}<0.001$ \\
& D12-ICD & $-0.264, \mathrm{P}=0.005$ \\
D13-ICD & $-0.250, \mathrm{P}=0.12$ \\
& $\mathrm{D} 14-\mathrm{ICD}$ & $-0.138, \mathrm{P}=0.088$ \\
\hline
\end{tabular}

Table 2 presents the output value of the coefficient of indirect effects and total effect completed with significance value $(\mathrm{P})$. It is one of the advantages of WarpPLS 3.0 so that researchers do not need to calculate manually to determine the coefficient of indirect relationships as a formula proposed by [16],[17].

Table 2. Indirect effect, total effects, effect size

\begin{tabular}{llc}
\hline & Path & Coefficients and P value \\
\hline Indirect effect & ICP-ICD & $-0.049, \mathrm{P}=0.179$ \\
Total effect & ICP-ICD & $0.254, \mathrm{P}=0.018$ \\
& ICP-PROFIT & $0.676, \mathrm{P}<0.001$ \\
\multirow{2}{*}{ Effect size } & PROFIT-ICD & $-0.072, \mathrm{P}=0.179$ \\
& ICP-ICD & 0.087 \\
& ICP-PROFIT & 0.457 \\
& PROFIT-ICD & 0.012 \\
\hline
\end{tabular}

Based on Table 3 can be seen that the indirect effect of ICP-ICD is -0049 , this result is actually a multiplication by using his formula Sobel (1986), namely multiplying the between path coefficient ICP to PROFIT (0.676) and PROFIT to ICD (-0.072). As described above, by 
using WarpPLS, researchers do not need to manually calculate the value of indirect effect of ICP-ICD (-0.049) because this program has produced output calculations the mediation.

a. Inner Assessment Model or Structural Model

Table 3 presents data R-squared, Q-squared and Full co-linearity of VIF. R-squared shows how the percentage of variance endogenous construct can be explained by an exogenous construct. Q-squared (usually called Stoner-Geisse coefficient) is an analogous to the Rsquared, but can only be obtained through re-sampling [15], while Full co-linearity of VIF is full co-linearity test result, which includes multi co-linearity in vertical, lateral and common method bias. Criteria for full vertical test is the value should be lower than 3.3 [18].

Table 3. R-Squared, Q-Squared, and Full collinearity VIF

\begin{tabular}{lll}
\hline R-squared & Q-squared & Full collinearity VIFs \\
\hline $\mathrm{PROFIT}=0.457$ & $\mathrm{PROFIT}=0.461$ & $\mathrm{ICP}=1.966$ \\
$\mathrm{ICD}=0.209$ & $\mathrm{ICD}=0.212$ & $\mathrm{PROFIT}=1.914$ \\
& & $\mathrm{ICD}=1.202$ \\
\hline
\end{tabular}

The test results showed that in this study the model there is no multi vertical, both vertical and lateral multi vertical and common method bias. It can be seen from the full vertical of VIF that was below 3.3 for all variables. Q-Square predictive relevance value is greater than 0 indicates that the model has a great relevance predictive value, so that this research model is accepted by the assessment criteria of Inner Model. Since both terms have been done and there is no problem either of Outer assessment Model and Inner Model, then the hypothesis testing can be done.

Especially for hypothesis testing 1, conducted a testing for the direct effect between ICP and ICD without entering a mediator variable. This stage is also a requirement (step) in the first assessment of the effects mediated by the three stages of the regression [16]. The test results of direct effect are presented in Figure 4 and Table 4.

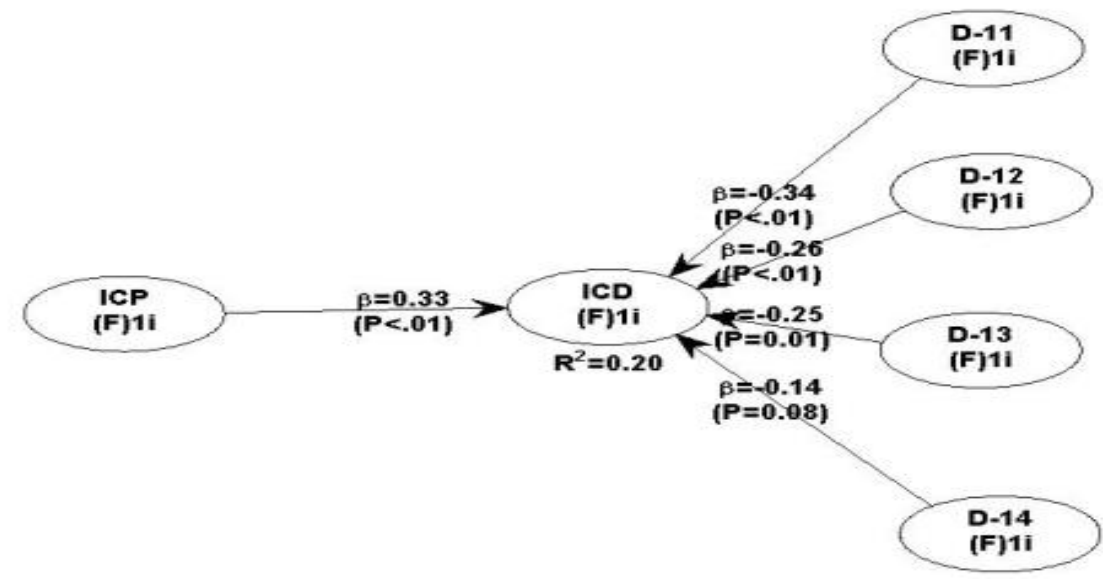

Fig 3. Output WarpPLS 3.0- Direct Effect

Based on the figure 3 is known that the path coefficient of direct relation (Direct Effect) of ICP-ICD showed a significant coefficient value as 0329 with value of $P=0.010$. For more 
details, the following will be presented detail WarpPLS output for testing directly in the Table 5.

Table 4. Output WarpPls 3.0 - Direct Effect

\begin{tabular}{llll}
\hline $\begin{array}{l}\text { Model fit indices } \\
\text { and } P \text { value }\end{array}$ & $\begin{array}{l}\text { Path coefficients } \\
\text { and } P \text { value }\end{array}$ & $\boldsymbol{R}^{\mathbf{2}}$ & Effect size \\
\hline $\mathrm{APC}=0.264, \mathrm{P}<0.001$ & $0.329, \mathrm{P}<0.010$ & 0.20 & 0.113 \\
$\mathrm{ARS}=0.205, \mathrm{P}=0.041$ & & & \\
$\mathrm{AVIF}=1.487$, Good if $<5$ & & & \\
\hline
\end{tabular}

Based WarpPLS output as shown in table 5 is known that criteria about the model fit has been met, where the P value of APC $(<0.001)$ and ARS $(0041)$ were $<0.005$ and AVIF value $<5$. The path coefficients resulting from this test is equal to 0329 with value of $p<0.010$. Thus, it can be concluded that the hypothesis 1 is accepted, this means that ICP has a positive effect on the ICD. The amount of ICP's ability to explain the variability of ICD is $20 \%$ means that there are $80 \%$ who are influenced by other variables not examined in this study.

The results of this study are consistent, unidirectional, and supporting the perspective of RBT theory (resources based theory) and the theory of signaling (signaling theory). In RBT theory, IC is a resource that can help companies to achieve competitive advantage. So according to signaling theory, IC good performance is a positive signal for the market. The better performance of IC-owned company, the managers will certainly disclose more information about its IC (e.g., through annual reports and voluntary disclosure), which aims to lure and attract the attention of stakeholders.

\subsection{Mediation Effect of PROFIT}

Testing for the effect of mediation was carried out in three stages regression [16]. The procedure in this context is as follows:

1. Estimating ICP direct effect on the ICD is by giving control to the independent variable (ICD) each year, without entering the mediator variable. The direct effect of this should be significant. This stage has been conducted when testing the hypothesis 1 (H1) and shows that there is a significant direct effect, $\mathrm{P}>0.05$.

2. Estimating the indirect effect simultaneously with the triangle SEM PLS models for each mediator, namely ICP-ICD, ICP-PROFIT and PROFIT-ICD (for mediator for PROFIT). Terms of the mediating effect that must be met is that the path ICP-PROFIT and PROFIT -ICD should be significant [15].

Using the data in Table 4 is known that the coefficient of direct effect ICP-ICD is significant at $\mathrm{p}=0.3290 .010(* * *)$. When testing the indirect effect (Table 3 ) it is known that the path coefficient value of ICP-ICD fell to 0.303 with $\mathrm{p}<0.001$ (***). However, PROFIT-ICD path indicates the direction of a negative relationship and not significant. Although ICP-PROFIT path showed a significant result, a condition for determining that the PROFIT into mediator factor in the relationship between ICP-ICD are not met because one of the path is not unidirectional and is also not significant. Thus, the second hypothesis is not supported. That is, PROFIT is not a mediator factor in the relationship between ICP with ICD.

The relationship between ROA-ICD that in this study becomes the cause of non-fulfillment of the criteria for the relationship ROA as mediator ICP-ICD can be seen from the output WarpPLS as presented in Table 4.3 which shows the path coefficient is -0072 and the value of p> 0.05 (not significant) showed that actual financial performance (profitability) is measured using the formula ROA does not affect the broad disclosure of intellectual capital (ICD) that 
they were measured using components ICD-in, so in this study ROA can't be mediator of relationship ICP and ICD because the relationship ROA-ICD-offs even insignificant.

These results are consistent with research of [10], has reviewed this relationship with a sample of public companies are included in the category of banks. The result is PROFIT not affecting the ICD. There is a tendency of companies that have high profitability was not important anymore made another attempt to influence the market through disclosure in the annual report, because of course the high ROA is enough weeks to appeal to the stakeholders (investors and the Customer) [10].

\section{Conclusion}

From this study can be taken an assumption that the good ICP is a positive signal for companies both Islamic Banks and Sharia Business Unit, so that it is really the manager will reveal information about the IC owned through the disclosure of intellectual capital when the company has a good performance IC (ICP) as well managed with maximum.

Different things happen when companies have felt to have a high profitability, because they will feel less important again made another attempt to affect the market for one of them through the disclosure of intellectual capital in the annual report, because ROA is high enough to be appeal for stakeholders. In this case, the manager is not too concerned though disclosure of intellectual capital (ICD) they will do it or not. Thus, ROA can't mediate the relationship between ICP with ICD.

\section{References}

[1] Williams, S. M. (2001). Is intellectual capital performance and disclosure practices related? Journal of Intellectual Capital, 2(3), 192-203.

[2] Ulum, I., Ghozali, I., \& Purwanto, A. (2014). Konstruksi Model Pengukuran Kinerja dan Kerangka Kerja Pengungkapan Modal Intelektual. JAMAL (Jurnal Akuntansi Multiparadigma), 5(3), 380-392.

[3] Ulum, I., Kharismawati, N., \& Syam, D. (2017). Modified value-added intellectual coefficient (MVAIC) and traditional financial performance of Indonesian biggest companies. International Journal of Learning and Intellectual Capital, 14(3), 207-219.

[4] Ulum, I., Rizqiyah, \& Jati, A. W. (2016). Intellectual Capital Performance: A Comparative Study between Financial and Non-Financial Industry of Indonesian Biggest Companies. International Journal of Economics and Financial Issues, 6(4), 1436-1439.

[5] Ulum, I. (2012). Investigasi Hubungan antara Kinerja Modal Intelektual dan Praktik Pengungkapannya dalam Laporan Tahunan Perusahaan. Jurnal Ekonomi Bisnis, 17(1), 3645.

[6] Hermawan, S., \& Mardiyanti, U. I. (2016). Intellectual capital dan kinerja keuangan perusahaan manufaktur high ic intensive. Benefit, 1(1), 70-78.

[7] Naovila, T. P., \& Wahyudin, A. (2015). Peran kinerja keuangan untuk memediasi pengaruh modal intelektual terhadap tingkat pengungkapannya. Accounting Analysis Journal, 4(3).

[8] Setyaningrum, H., Zuni Barokah, S., \& Com, M. (2015). Analisis pengaruh modal intelektual dan luas pengungkapannya terhadap kinerja dan nilai perusahaan (Studi pada 
Perusahaan Farmasi, Telekomunikasi, dan Perbankan yang Terdaftar di Bursa Efek Indonesia). Universitas Gadjah Mada.

[9] Miller, J., \& Whiting, R. (2005). Voluntary disclosure of intellectual capital and the 'hidden value'. Paper presented at the AFAANZ Conference, Melbourne.

[10] Ulum, I. (2015b). Peran Pengungkapan Modal Intelektual dan Profitabilitas dalam Hubungan antara Kinerja Modal Intelektual dan Kapitalisasi Pasar. Paper presented at the Simposium Nasional Akuntansi XIIIV.

[11] Ulum, I. (2015c). Peran Pengungkapan Modal Intelektual dan Profitabilitas dalam Hubungan antara Kinerja Modal Intelektual dengan Kapitalisasi Pasar. Unpublished Disertasi Tidak Dipublikasikan, Universitas Diponegoro, Semarang.

[12] Ulum, I. (2015a). Intellectual Capital. Malang: UMM- Press.

[13] Ghozali, I. (2011). Structural Equation Modeling Metode Alternatif Dengan Partial Least Square (PLS) Semarang Badan Penerbit UNDIP.

[14] Guthrie, J., Petty, R., Ferrier, F., \& Wells, R. (1999). There is no accounting for intellectual capital in Australia: A review of annual reporting practices and the internal measurement of intangibles. Paper presented at the OECD Symposium on Measuring and Reporting of Intellectual Capital, Amsterdam.

[15] Sholihin, M., \& Ratmono, D. (2013). Analisis SEM-PLS dengan WarpPLS 3.0 untuk Hubungan Nonlinier dalam Penelitian Sosial dan Bisnis.

[16] Baron, R. M., \& Kenny, D. A. (1986). The moderator-mediator variable distinction in social psychological research: Conceptual, strategic, and statistical considerations. Journal of personality and social psychology, 51(6), 1173.

[17] Kock, N. (2015). Common method bias in PLS-SEM: A full collinearity assessment approach. International Journal of e-Collaboration (IJeC), 11(4), 1-10.

[18] Preacher, K. J., \& Hayes, A. F. (2004). SPSS and SAS procedures for estimating indirect effects in simple mediation models. Behavior research methods, instruments, \& computers, 36(4), 717-731. 